\title{
Taxonomic, DNA Barcoding and Phylogenetic Reassessment of the Egyptian Ephedra L. (Ephedraceae)
}

\author{
Ahmed Faried $^{1 *}$, Ahmed EL-Banhawy ${ }^{2}$ and Mesfer Elqahtani ${ }^{3}$ \\ ${ }^{1}$ Botany and Microbiology Department, Faculty of Science, Assiut University, Assiut, Egypt \\ ${ }^{2}$ Botany Department, Faculty of Science, Suez Canal University, Ismailia, Egypt \\ ${ }^{3}$ Biology Department, College of Science and Humanities, Dawadmi, Shaqra University, Saudi Arabia
}

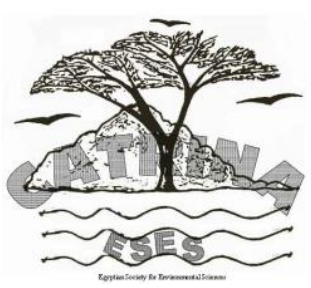

\begin{abstract}
This study attempts to carry out a critical revision for the genus Ephedra in Egypt based on morphological characters for leaf, stem and flower. DNA sequencing data used for the first time for DNA barcoding of the family Ephedraceae in Egypt. One chloroplast marker-intergenic spacer $t r n-\mathrm{H} / p s b-\mathrm{A}$ and another nuclear Internal Transcribed Spacer (ITS) were sequenced to authenticate the identification and to reconstruct the phylogenetic relationships of the Egyptian Ephedra species. The results revealed that, the name of Ephedra ciliata Fischer and C. A. Mey., was illegitimate and became a synonym to Ephedra foliata Boiss., which reported here as accepted name. The current work recommends using the DNA barcode as a tool for species identification of Ephedra species as well as other gymnosperms in Egypt.
\end{abstract}

ABSTRACT Keywords: Ephedra, ITS, Gymnosperms, Gnetales, Systematics, Phylogenetic, trn-H/psb-A.

\section{INTRODUCTION}

Family Ephedraceae includes around 68 species in the genus Ephedra L. (Christenhusz and Byng, 2016). In addition to Gnetum and Welwitschia, the genus Ephedra comprise Gymnospermous Gnetales group, which characterized by nonflowering seed plants with limited evolutionary history (Ickert-Bond and Wojciechowski, 2004; Rydin et al., 2006). Despite the numerous studies in the past century, the systematic position of the Gnetales is still poorly understood and in most morphological analyses a close affinity between Gnetales and higher angiosperms was implied (Mundry and Stützel, 2004).

Species of Ephedra are equally distributed in both old and new world (Ickert-Bond, 2003), they are usually xeromorphic dioecious shrubs or under shrubs with green branches, leaves are opposite or whorled; often reduced to membranous sheathes (El Hadidi, 2000). The genus shows high tolerability against extraordinary aridity. This leads to reduction in vegetative growth. Little taxonomic emphasis was given for such xeric Gymnosperms in Egypt. Usually, the vegetative stages of Ephedra are vigorous in the field as well as in preserved specimens. Moreover, the rare opportunity for investigator to find plant and/or herbarium specimen with mature sexual phases represent a great challenge for species delimitation. When morphologically-based biosystematics of any group of plants has been so troublesome, the utilization of DNA sequencing data to discriminate between problematic taxa and to infer phylogenies becomes unavoidable choice (Ickert-Bond and Wojciechowski, 2004).

Ephedra has been a subject of many phylogenetic studies (Huang et al., 2005; Ickert-Bond and Rydin, 2011; Ickert-Bond et al., 2009; Ickert-Bond and Wojciechowski, 2004; Long et al., 2004; Rydin et al., 2010). According to Ickert-Bond and Rydin (2011), the morphological and molecular diversity within Ephedra still limited and more phylogenetic investigations is needed to understand the evolution of this genus. Rydin et al. (2006) reported that all species of Ephedra are very closely similar in gross. Monophyly of the genus was considered, however this assumption has not been investigated thoroughly (Huang et al., 2005; Price, 1996; Rydin et al., 2002).

The genus Ephedra has been studied world-widely regarding the systematics significances by (AnuevaAlmanza and Fonseca, 2011; Cutler, 1939; Freitag and Maier-Stolte, 1996; Ickert-Bond, 2003; Price, 1996; Stapf, 1889). Huang et al. (2005) used chloroplast marker matK gene and nuclear marker ITS for subgeneric classification of the genus. However, in Egypt, Ephedra and other Gymnosperms have never been subjected to taxonomic revision except in the context of floras (Boulos, 1999; El Hadidi, 2000; Täckholm, 1974).

In Egypt, Ephedraceae is one of the two families belonging to subdivision Gymnospermae. The Egyptian Ephedraceae is represented by only Ephedra L. (Boulos, 1999). Täckholm (1974) reported four species of genus Ephedra namely: E. alata Decne., E. aphylla Forssk., E. ciliata Fischer and C. A. Mey. and E. campylopoda C. A. Mey, while Boulos (1999) added E. pachyclada Boiss. as a new record to the flora of Egypt, he consid-ered E. campylopoda C. A. Mey. as a synonym to E. foeminea Forssk. Boulos (op. cit.) enumerated five taxa of Ephedra, viz. Ephedra alata Decne., Ephedra aphyl-la Forssk., Ephedra ciliata Fischer and C. A. Mey., Ephedra foeminea Forssk. and Ephedra pachyclada Boiss. subsp. sinaica (Riedl) Freitag and Maier-Stolte.

The nomenclatural and systematics background of many of the Mediterranean species of Ephedra have been particularly complex, and most of names now treated as a synonymy (e.g., E. alte C. A. Mey., E. campylopoda C. A. Mey. and E. ciliata Fischer and C. A. Mey.) have been widely used in the literatures (Price, 1996).

Ephedra has been used for treatment of asthma and 
bronchitis. It has been proven to have potent efficacy to relief symptoms of cold and flu such as fever, cough and nasal congestion (Zheng, 1997). Ephedra alata has been used by Bedouins in Sinai Peninsula in folk medicine as treatment herb for Central Nervous Disorders (CNS) and several other healing uses (Eissa et al., 2014).

Kress et al. (2005) postulated that the DNA barcoding aims to develop a universal database of specific DNA sequences which might be used for unknown species identification and taxonomic delimitations. The first successful attempt of this developing technique was using a DNA sequence of Cytochrome oxidase 1 (CO1) mitochondrial gene especially in animals. In plants, launching this step was challenging, relevant to the selection of standard and universal candidate marker to be used as plant DNA barcode. After several broad screenings of gene regions in the plant genome, three plastids $(r b c \mathrm{~L}, m a t \mathrm{~K}$, and $t r n-\mathrm{H} / p s b-\mathrm{A})$ and one nuclear (ITS) gene regions have become the standard barcode of choice in most investigations for plants.

Techen et al. (2014) recommended the using of twolocus barcode versus a three-locus barcode (mat $\mathrm{K}+$ $r b c \mathrm{~L}+t r n-\mathrm{H} / p s b-\mathrm{A})$. They pointed out; the two-locus barcode was preferred to avoid the increased costs of sequencing. The barcode combination $r b c \mathrm{~L}+$ mat $\mathrm{K}$ was the preferred choice as barcode of medicinal plants.

A search of the literature in SciFinder (a chemical abstracts service database) from 2010 to 2013 resulted in 60 publications. In the literature analyzed in this review, a total of 17 barcode regions ( $m a t \mathrm{~K}, r b c \mathrm{~L}$, ITS, ITS2, trn-H/ $p s b-\mathrm{A}, a t p \mathrm{~F}-a t p \mathrm{H}, \mathrm{ycf} 5, p s b \mathrm{~K}-\mathrm{I}, p s b \mathrm{M}$ $\operatorname{trn} \mathrm{D}, \operatorname{rps} 16, \operatorname{cox} \mathrm{I}, n a d 1, \operatorname{trn} \mathrm{L}-\mathrm{F}, \mathrm{rpoB}, \operatorname{rpo\mathrm {C}} 1$, atp $\mathrm{F}-$ $a t p \mathrm{H})$ of medicinal plants were reported to aid in the authentication and identification of medicinal plant materials. Most barcoding regions mentioned in the literature were the ITS region (26 references), trn-H/ $p s b$-A (21 references), matK (19 references), and $r b c \mathrm{~L}$ (14 references). Further genomic regions used for barcoding were ITS2 (9 references), rpoC1 (6 references), rpoB (4 references), and trnL-F (3 references).

Due to lack of previous taxonomic studies of Ephedra in Egypt, this study attempts to carry out a critical revision for the genus Ephedra in Egypt based on morphological characters for leaf, stem and flower. Moreover, the present study seeks to test the monophyly of Ephedra species in Egypt; provides a preliminary insight of the validity of the traditional taxonomic divisions into sections.

\section{MATERIALS AND METHODS}

\section{A. Specimen collections}

The work was based on collections kept in different Egyptian herbaria: ASTU, CAI, CAIM, as well as SCUI and on photos of type specimens in C, B, BM, G, HUJ, JE, K, MPU and P herbaria. The code of herbarium abbreviation follows Thiers (2017). Photos of the type specimens were seen by the authors indicated by "!". The specimens were identify according to (Täckholm, 1974) and (Boulos, 1999 and 2009). Specimens were exa-mined by Olympus SZ61 stereomicroscope provided with a digital Olympus camera SC100. Table (1) summarizes the available data about the taxa under investigation as reported in the earlier works for the flora of Egypt. The distribution map of Ephedra species was created based on the distribution regions that cited in Boulos (1999) Map (1).

\section{B. DNA Extraction}

As Ephedra is characterized by minute leaves, it was difficult to obtain reasonable amount of fresh and/or dry leaves for DNA extraction. Instead, the total genomic DNA was extracted from $0.25-1.00$ gm of stems grounded in liquid nitrogen. Methods of (Doyle and Doyle, 1987) was implied with modification by adding $2 \%$ PVP 40 (polyvinyl pyrrolidone) to the buffer (2\% CTAB, $20 \mathrm{mM}$ EDTA, $1.4 \mathrm{mM} \mathrm{NaCl}$ and $100 \mathrm{mM}$ Tris$\mathrm{HCl}, \mathrm{pH} 8$ ) to improve the quality of DNA.

\section{PCR amplification and DNA Sequencing}

Double-stranded DNA was amplified by the Polymerase Chain Reaction (PCR) using previously published primers sets for the selected DNA markers. Thermal cyclers Veriti'TM Dx 96-well Thermal Cycler, $0.2 \mathrm{ml}$ (Applied Biosystems®) was used. The reaction usually carried out in $25 \mu \mathrm{l}$ for bidirectional sequencing using (BioMix ${ }^{\circledR}$, Bioline, UK) a complete ready to use $2 \mathrm{x}$ reaction mix containing an ultra-stable DNA polymerase according to the manufacturer's instructions. To enhance amplification Bovine Serum Albumin (BSA) added to the PCR aliquot prior to the start of the reaction.

\section{Bioinformatics analyses}

a) DNA barcoding

DNA sequencing data was used for the first time for DNA barcoding of the family Ephedraceae in Egypt. One chloroplast marker-intergenic spacer $t r n-\mathrm{H} / p s b-\mathrm{A}$ and another nuclear Internal Transcribed Spacer (ITS) were sequenced to authenticate the identification and to reconstruct the phylogenetic relationships of the Egyptian Ephedra species. Sequences for trn-H/psb-A and ITS loci from Ephedra species were submitted to GeneBank database with accession numbers (Table 2). The trn-H/psb-A and ITS loci of the genus Ephedra in Egypt were compared with other sequences of non-Egyptian species belonging to the genus Ephedra retrieved from Gene-Bank database. Multiple alignment of the sequences performed with CLUSTAL W2 (www.ebi.ac.uk/ Tools/clustalw2) and T-COFFEE (www.ebi.ac.uk/Tools/t-coffee). DNA barcode-based trees were obtained by using Neighbor-Joining and Kimura-2 parameter to evaluate the relationships of species and compare the DNA barcode-based classifications of species with classical taxonomic classifications of species, (Fig. 1). Gene-bank database search via Basic Local Alignment Search Tool (BLAST) was done with the newly generated DNA sequences for both loci, (Table 2).

b) Phylogenetic analysis

Bayesian phylogenetic Inferences (BI) were conducted using the Mr Bayes software (ver. 3.2) (Ronquist et al., 2012). Three independent datasets were analyzed. These were made up of two types: single locus datasets (2 datasets) and a concatenated dataset of chloroplast DNA (cp DNA) plus nuclear DNA (nr DNA). The opti- 
mal nucleotide substitution model was selected for each alignment via the AIC criterion (Akaike, 1974) using PAUP version 4.0 (Swofford, 2003) and the Mr Modelblock command from Mr Model test (Nylander, 2004). For each matrix, two independent Bayesian analyses were performed to check for convergence (Miller et al., 2002), with four chains per analysis and trees sampled every specified number of generations relevant to each dataset. All compatible trees were calculated in Mr Bayes. A plot of negative log .

Likelihoods against generation time were done using Markov chain Monte Carlo (MCMC Trace Analysis). Tool Version 1.6.0, 2003 to establish the burn in (Rambaut et al., 2013). Trees found before reaching stability were pruned out and the rest used to compile an all compatible tree. All compatible trees were exported to tree Graph2 (ver. 2.0.50-314 beta) software for visualization and editing (Stöver and Müller, 2010). Posterior Probabilities (PP) were used to measure clade support.

\section{E. Taxonomic classifications of taxa}

The most important sectional treatment of the genus Ephedra was carried out by Stapf (1889), in which the genus was divided into three major sections based on bracts of female cones: Alatae, Ephedra and Asarca. The Egyptian taxa of Ephedra represented only in two sections: Alatae and Ephedra. Table (1) shows the sectional and tribal classification of Egyptian Ephedra according to classification of Stapf (1889).

Table (1): Ephedra species reported by the different authors who are concerned with the flora of Egypt, including the current study (+ = present, $-=$ absent, $\mathrm{x}=$ recorded as a synonym, 1= Forsskål 1775, 2= Boissier $1867-1879,3=$ Muschler 1912, 4= Täckholm 1956, 5= Täckholm 1974, 6= El Hadidi \& Fayed 1994/1995, 7= El Hadidi 2000, 8= Boulos 2009, 9= Present study 2018).

\begin{tabular}{|c|c|c|c|c|c|c|c|c|c|c|c|}
\hline Section & Tribe & Taxa & 1 & 2 & 3 & 4 & 5 & 6 & 7 & 8 & 9 \\
\hline Alatae & Tropidolepides & Ephedra alata Decne. & - & + & + & + & + & + & + & + & + \\
\hline \multirow{6}{*}{ Ephedra } & \multirow{5}{*}{ Scandentes } & $\begin{array}{l}\text { Ephedra aphylla Forssk. } \\
=\text { Ephedra alte C. A. Mey }\end{array}$ & $\mathrm{X}$ & $\mathrm{X}$ & + & $\mathrm{X}$ & + & + & + & + & + \\
\hline & & Ephedra foliata Boiss. & & & & & & & & & \\
\hline & & $=$ Ephedra ciliata Fischer \& C. A. Mey. & - & + & - & + & + & $\mathrm{X}$ & + & $\mathrm{X}$ & + \\
\hline & & $\begin{array}{l}\text { =Ephedra peduncularis Boiss. \& Hausskn. } \\
\text { Ephedra foemina Forssk. }\end{array}$ & & & & & & & & & \\
\hline & & $\begin{aligned}= & \text { Ephedra campylopoda } \mathrm{C} . \text { A. Mey. } \\
= & \text { Ephedra fragilis Desf. subsp. campylopoda (C. A. Mey.) } \\
& \text { Asch. \& Graebn. }\end{aligned}$ & $\mathrm{X}$ & $\mathrm{X}$ & - & - & $\mathrm{X}$ & - & - & + & + \\
\hline & Pachyclada & $\begin{array}{l}\text { Ephedra pachyclada Boiss. } \\
=\text { Ephedra sinaica } \text { Riedl. }\end{array}$ & - & + & - & - & - & + & + & + & + \\
\hline
\end{tabular}

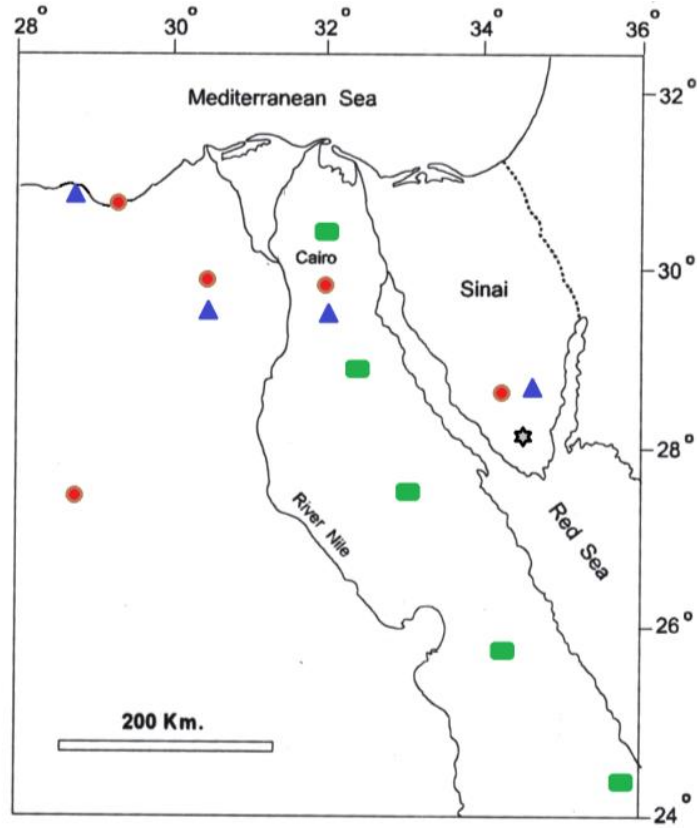

Map (1): Distribution of Ephedra species in Egypt. Ephedra alata $(\mathbf{O})$, Ephedra aphylla (), Ephedra foliate $(\square)$, Ephedra pachyclada subsp. sinaica (ઐ).

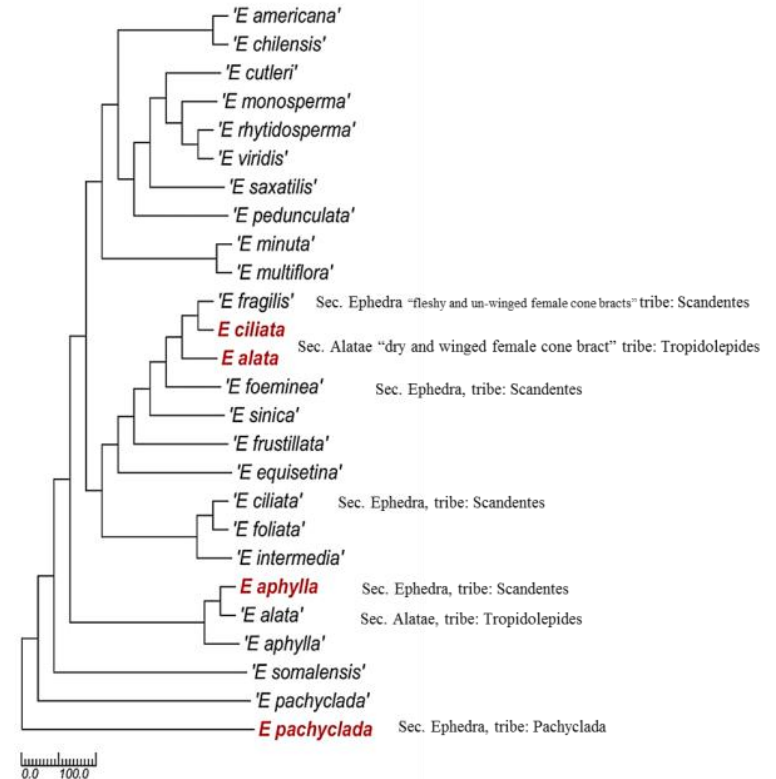

Figure (1): Cladogram of Neighbor Joining tree (NJ) of Egyptian Ephedra species inferred from combined dataset of sequences of two markers $t r n-\mathrm{H} / p s b$-A, and ITS species. Red typos represent the Egyptian species with its corresponding sectional classification. 
DNA barcoding and phylogenetic reassessment of the Egyptian Ephedra

Table (2): Similarity search using BLAST tool and identification status of Egyptian Ephedra species.

\begin{tabular}{|c|c|c|c|c|c|c|}
\hline $\begin{array}{c}\text { Query } \\
\text { (Egyptian } \\
\text { species) }\end{array}$ & $\begin{array}{c}\text { Accession } \\
\text { number }\end{array}$ & BLAST Result & $\begin{array}{l}\text { Accession } \\
\text { number * }\end{array}$ & Locus & $\begin{array}{l}\text { Identification } \\
\text { (\%similarity) }\end{array}$ & $\begin{array}{c}\text { Identification } \\
\text { status }\end{array}$ \\
\hline Ephedra alata & MG550042 & $\begin{array}{l}\text { Ephedra fragilis } \\
\text { (synonym) }\end{array}$ & AY849363.1 & $t r n-\mathrm{H} / p s b-\mathrm{A}$ & $95 \%$ & Succeeded \\
\hline E. aphylla & MG569946 & E. aphylla & GU968569.1 & ITS & $98 \%$ & Succeeded \\
\hline E. pachyclada & MG550043 & $\begin{array}{l}\text { E. sinica } \\
\text { (synonym) }\end{array}$ & GQ463516.1 & $t r n-\mathrm{H} / p s b-\mathrm{A}$ & $95 \%$ & Succeeded \\
\hline E. pachyclada & MG569945 & E. pachyclada & AY755779.1 & ITS & $99 \%$ & Succeeded \\
\hline E. ciliata & MG550041 & E. foeminea & KT934791.1 & $t r n-\mathrm{H} / p s b-\mathrm{A}$ & $92 \%$ & Failed \\
\hline
\end{tabular}

*Accession number of non-Egyptian species retrieved from database

\section{RESULTS}

\section{Systematic treatment}

Ephedra L., Sp. Pl. ed. 1: 1040 (1753).

Type species: Ephedra distachya L. Sp. pl. 2: 1040 (1753).

According to Mabberley (2008) and Christenhusz and Byng (2016), Ephedra consists of about 68 species distributed between the old and new world and native to arid and semiarid regions of Europe, $\mathrm{N}$ Africa WN America, S America and Asia. Our taxonomic revision of the genus in Egypt revealed the presence of 5 species including one subspecies (representing in 2 sections) as shown in table (1):

\section{A. Sect. Alatae Stapf}

Characterized by having a dry and winged female cone bract.

\section{Tribe Tropidolepides Stapf}

1. Ephedra alata Decne., Ann. Sci. Nat. Bot., Sér. 2, 2: 239 (1834).

Type: Egypt: Sinai, Algdé Arab. Désert de Suez, Bové, N. 215, 1 June 1832. Isotype: K (K000076236 and K000076235 photos!), G (G-355819/1), MPU (MPU027036 photo!); Lectotype: P (P00738802). Isolectotype: P (P00738804).

Distribution: In Egypt: The Oases of the western desert, the Mediterranean coastal strip and all the deserts of the country including that of Sinai (Map 1). General distribution: North Africa, Palestine, Arabia, Iraq.

Ecology: Desert sandy plans.

Representative specimens: Suez: Cairo-Suez desert road, 15 March 1974, El-Hadidi et al. s.n. (CAI); Kilo 20 on Cairo-Suez road, 10 March 1930, F. W. Oliver s.n. (CAI); Kilo 21 on Cairo-Suez road, 9 June 1971, Saad et al. s.n. (CAIM); Wadi Katamiya, 11 March 1960, V. Täckholm et al. s.n. (CAI); $30 \mathrm{~km}$, south of Suez, 4 Oct. 1989, El Garf s.n. (CAI); Wadi Araby, between the two Galalas, 4 Feb. 1960, V. Täckholm et al. s.n. (CAI); South Galala, cretaceous foot hills, 6 Feb. 1960, V. Täckholm et al. s.n. (CAI). Cairo: Wadi Degla, west Maadi, 15 April 1979, M. Atta et al. 115 (CAIM); Wadi Hoff, March 1980, Fayed and el-Naggar s.n. (ASTU). Sinai: Wadi Feiran, 10 May 1956, V. TäckhoIm s.n. (CAI); Abo Zeinema, 19 Feb. 1969, M. Abdalla 539 (CAIM); Wadi El-Hamammat, January 1962, ElHadidi s.n. (ASTU); Wadi Fereeh, 24 April 1961, ElHadidi s.n. (ASTU); Wadi El-Tayeb, 24 April 1961, El-
Hadidi s.n. (ASTU); At the entrance of wadi Feiran, 21 Aptil 1961, V. Täckholm et al. s.n. (CAI); Wadi Feiran, 16 April 1962, M. Abdalla et al. 794 (CAIM); Wadi Hamamet Faroan, near the red sea, 16 May 1956, V. Täckholm s.n. (CAI); Wadi Abu Khodirate, 85 km. west of Zafarana, 13 April 1997, M. Fadel s.n. (CAI).

\section{B. Sect. Ephedra Stapf}

Characterized by having fleshy and un-winged female cone bracts.

\section{Tribe Scandentes Stapf}

2. Ephedra aphylla Forssk., Fl. Aegypt.-Arab. 170 (1775).

Type: Palestine: Jaffa in sepibus, Bormüller Iter Syriacum 1749, 12 May 1897. Designated by Freitag and Maier-Stolte (1989). Iso-lectotype: B (B100296982 photo!), Neotype: JE (JE00006800 photo!); Isoneotypes: K (K000459012 photo!), BM (BM000884450 photo!).

Synonym: Ephedra alte C. A. Mey., Monogr. Ephedra, Mém. Acad. Sci. Pétersb. 5: 75 (1846).

Distribution: In Egypt: The Mediterranean coastal strip and all the deserts of the country including that of Sinai (Map 1). General distribution: Northeast Africa, Syria to northern Arabia.

Ecology: Calcareous slopes and wadi beds.

Representative specimens: Mediterranean coastal strip: Before Mersa Matrouh, on the road, 3 May 1966, V. Täckholm s.n. (CAI); Saniet Hagg Ayyad, wadi ElHabes, before Agiba, 23 March 1974, V. Täckholm s.n. (CAI); Ras El-Hekma, 25 May 1954, Migahid and Shafey s.n. (CAI); Burg El-Arab, Roman Cistern, 9 March 1978, Merxmüller et al. s.n. (CAI); 11 March 1978, ElHadidi and A. Soliman s.n. (CAI); 18 Sept. 1970, Mahdi s.n. (CAI); Mariout, 12 Aug. 1928, M. Hassib s.n. (CAI); 18 March 1931, Oliver s.n. (CAI); 14-17 March 1958, V. Täckholm s.n. (CAI); 30 April 1976, J. Chrtek s.n. (CAI); Alexandria, Vectoria, 25 Aug. 1921, J. Brown s.n. (CAIM). Cairo: Wadi Hoff, 11 April 1978, G. Fahmy s.n. (CAI); Giza, El-Busseili, 23 Sept. 1971, Iman et al. (CAI). Sinai: entrance of wadi El-Arbaein, 23 April 1961, Jack et al. s.n. (CAI); Deir El-Rahba garden, Saint Catherin, 5 May 1939, M. Drar 356 (CAIM); Wadi El-Arbaein, Saint Catherin, 18 May 1988, M. Kassas s.n. (CAI); Wadi El-Kid, 28 March 2004, 28.34474 N, 34.17169 E, A. Fayed et al. s.n. (ASTU); Wadi Allalaqi, 1963, M. Abdalla et al. s.n. (CAIM). Gebel Elba, 28 Feb. 1938, Shabetai 5146 (CAIM). 
3. Ephedra foliata Boiss., Diagn. Pl. Orient. 7: 101 (Jul.-Oct. 1846).

Type: Iran: Islamic Republic of Gilan, Aucher-Eloy, $P$. M. R. 5338, no date. Isotype: $\mathrm{K}$ (K000456219 photo!), P (P00738820 photo!); Iso-lectotype: BM (BM 000884470 photo!).

According to the recent database of World Checklist of Selected Plant families WCSP (2017), Ephedra ciliata Fischer and C. A. Mey. was illegitimate and became a synonym to Ephedra foliata Boiss. which reported as accepted name.

Synonyms: Ephedra ciliata Fischer and C. A. Mey., Monogr. Ephedra, Mém. Acad. Sci. Pétersb. 4: 100 (Mar. 1846). nomen nudum,

Ephedra peduncularis Boiss. and Hausskn., Fl. Orient. 5: 716 (1884).

Distribution: In Egypt: Desert east of the Nile including that of Sinai, Gebel Elba and the surrounding mountainous regions (Map 1). General distribution: North and East Africa, Arabia, eastwards to India.

Ecology: Scrambling on shrubs and trees, rocky slopes.

Representative specimens: Sinai: Red sea, Gebel Hamata, 7 Feb. 1961, V. Täckholm et al. s.n. (CAI); Farsh Deghymat, 283269 N, 335481 E, Saint Catherin, 18 April 2008, Ahmed EL-Banhawy (SCUI); Wadi Adaib, Saint Catherin, 20 Jan. 1930, M. Hassib s.n. (CAI); Wadi Reem, 28.66806 N, 33.66742 E, 23 April 2004, A. Fayed et al. s.n. (ASTU); Wadi Gebal, 28.3228 N, 33.5253 E, 28 April 2004, A. Fayed et al. s.n. (ASTU); Wadi Alletehi, 28.09732 N, 34.04545 E, 11 April 2004, A. Fayed et al. s.n. (ASTU); Wadi Al Ratam, 28.23901 N, 34.23850 E, 28 March 2004, A. Fayed et al. s.n. (ASTU); Gebel Serbal region, wadi Aleyaat, 28.6686 N, 33.65377 E, 22 April 2004, A. Fayed et al. s.n. (ASTU). Qena: Gebel Hamra Dom, 9 Feb. 1932, M. Drar s.n. (CAIM). Gebel Elba: 4 Jan. 1933, M. Hassib s.n. (CAI); Sept. 1936, M. Drar s.n. (CAIM); Wadi Santit, 23 Jan. 1962, V. Täckholm et al. (CAI).
4. Ephedra foeminea Forssk., Fl. Aegypt.-Arab. 219 (1775).

Type: Turkey: Gökceada, P. Forsskål 1246, July 1761. Lectotype: C (C10002224 photo!).

Synonyms: Ephedra campylopoda C. A. Mey., Monogr. Ephedra, Mém. Acad. Sci. Pétersb. 4: 107 (1846).

Ephedra fragilis Desf. subsp. campylopoda (C. A. Mey.) Asch. and Graebn., Syn. Mitteleur. Fl. 1: 258 (1897).

Distribution: In Egypt: Sinai Peninsula. General distribution: Southern Arabia and Ethiopia.

Ecology: Rocky cliffs.

Representative specimens: no specimens were seen. Notes: The conservation status of Ephedra foeminea is endangered as reported in Plant Red Data Book of Egypt (El-Hadidi et al., 1991).

\section{Tribe Pachyclada Stapf}

5. Ephedra pachyclada Boiss., Fl. Orient. 5: 713 (1884) subsp. sinaica (Riedl) Freitag and Maier-Stolte, Edinb. J. Bot. 49: 92 (1992).

Type: Egypt: South Sinai, $10 \mathrm{~km}$. S. of Nebi Salah, in fissures of flat granite, 1350-1400 m. A. Danin s.n., 4. April 1971. (HUJ).

Synonym: Ephedra sinaica Riedl, Notes Roy. Bot Gard. Edinb. 38: 291 (1980).

Distribution: In Egypt: Sinai Peninsula (Map 1). General distribution: Arabia, extending eastwards to Iran and Pakistan.

Ecology: Rocky cliffs and slopes.

Representative specimens: Cairo: Giza, 15 Oct. 1963, El-Mahdi s.n. (CAI). Sinai: Wadi El-Kid, 28.34474 N, 34.17164 E, 27 March 2004, A. Fayed et al. s.n. (ASTU); Wadi Gebal region, Wadi Al-Talaa Al-Kabera, 28.2345 N, 33.5245 E, 28 March 2004, A. Fayed et al. s.n. (ASTU); Ain Al-Tofaha, 28.3254 N, 33.5626 E, 28 March 2004, A. Fayed et al. s.n. (ASTU).

\section{Key to the species of Ephedra in Egypt: (Figures 2-5, Table 3)}

1- Twigs flexible; gynodioecious; seed up to $1 \mathrm{~mm}$ length; usually completely covered by bracts,

E. foeminea

- Twigs rigid; dioecious; seed up to $7 \mathrm{~mm}$ length; upper part of seed emerging from bracts 2

2. Leaves 10-17 mm; stem surface ciliate; bracts of female cone 6-8 mm length in 2 pair..... E. foliata

- Leaves 2-3 mm; stem surface smooth or papillose; bracts of female cone 3-5 mm length in more than 2 pair. .... 3

3. Surface of stem smooth; female cone bracts free, in 5 pairs, dry, marginal winged, 2 seeds; anthers distinctly stipitate ...... E. alata

- Surface of stem papillose; female cone bracts fused; in 3-4 pairs; fleshy; marginal un-winged, 1 seed, anthers sessile .............4

4. Margins of leaves and bracts ciliate; seed up to $7 \mathrm{~mm}, 3-4$ anthers per one flower; stamens not exceeding 3 mm length... E. aphylla

- Margins of leaves and bracts glabrous, seed up to $5 \mathrm{~mm}, 5-8$ anthers per one flower; stamens exceeding $3 \mathrm{~mm}$ length.. E. pachyclada subsp. sinaica

\section{DNA barcoding}

In correlation of the Egyptian Ephedra species; chloroplast genome $t r n-\mathrm{H} / p s b-\mathrm{A}$, and the nuclear genome (ITS) experienced the standardized DNA barcoding. By examination, $t r n-\mathrm{H} / p s b-\mathrm{A}$ had a value of divergence $(0.33 \%)$, while ITS had a much lower divergence value $(0.20 \%)$. Although the sequence of ITS was shorter than $800 \mathrm{bp}$, we included them in the investigation considering their high interspecific variability. The current interspecific investigation over all available taxa confirmed variation between the two markers as for the three barcoding criteria: ease of amplification, length of the sequence, and sequence divergence.

The current study managed to produce two newly generated sequences of ITS of Ephedra aphylla and Ephedra pachyclada from Egypt. On the other hand, the chloroplast intergenic spacer $t r n-\mathrm{H} / p s b$-A was sequenced for all accessible taxa except for Ephedra foeminea 
where no accessible specimen neither discovered nor gathered all through Egypt recently. Genebank database search via BLAST online similarity search inveterate morphology with the available DNA sequences which are then corresponding to an online reference collection (NCBI's GeneBank) supports to authorize identification, retrieved inquires results shown in table
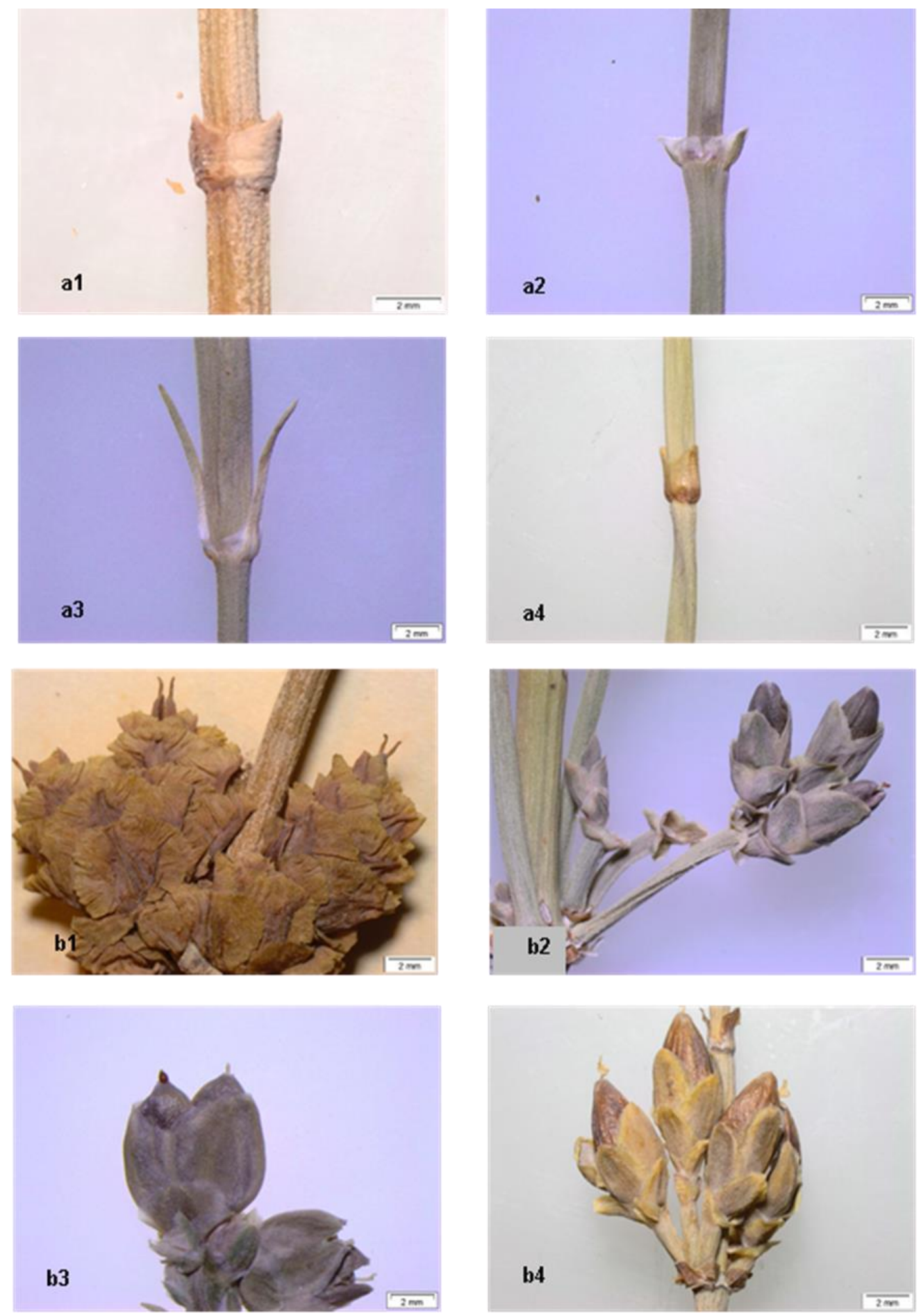

(2). Utilizing two markers, DNA barcoding has been flourished to affirm identification of Ephedra pachyclada while single DNA barcoding was prevailing to affirm the identification of two taxa Ephedra alata and Ephedra aphylla. In contrast, single marker DNA barcoding failed to affirm the identification of Ephedra foliata (Table 4, Figures 1, 6, 7 and 8).
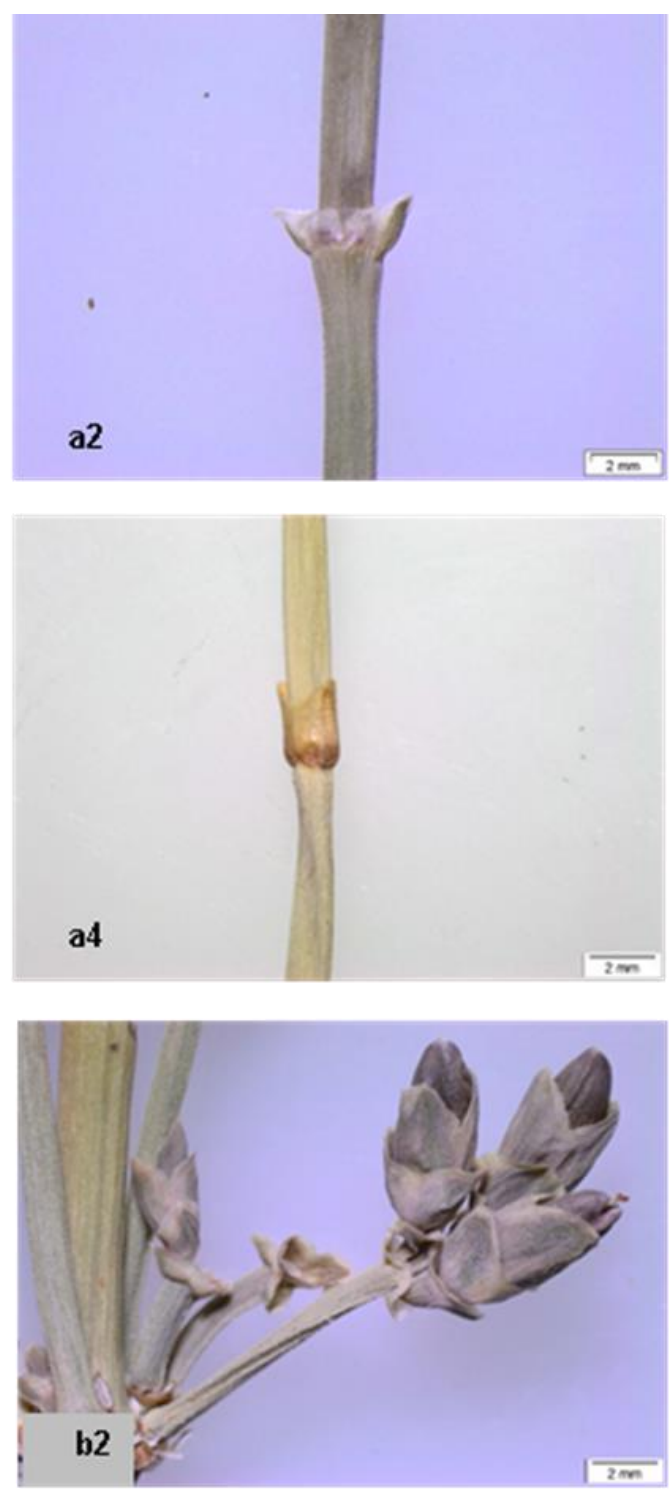

Figure (2): Morphology of Ephedra species, a, vegetative shoot showing leaves arrangement; b, female cone: 1, E. alata; 2 , E. aphylla; 3, E. foliata; 4, E. pachyclada subsp. sinaica.

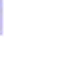

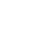


Faried, A. et al.
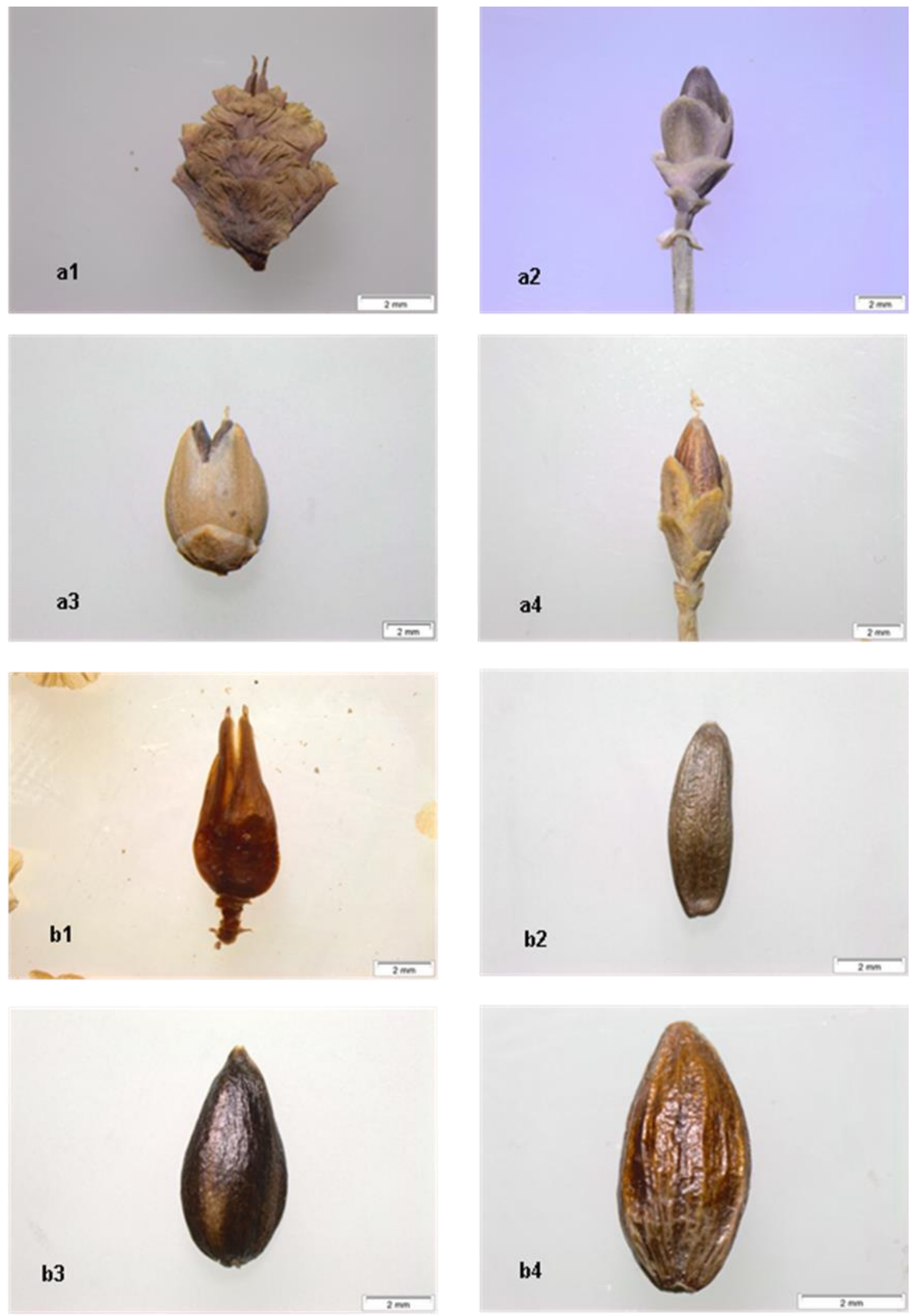

Figure (3): a, an enlarged female strobilus; b, seed: 1, E. alata; 2, E. aphylla; 3, E. foliata; 4, E. pachyclada subsp. sinaica. 

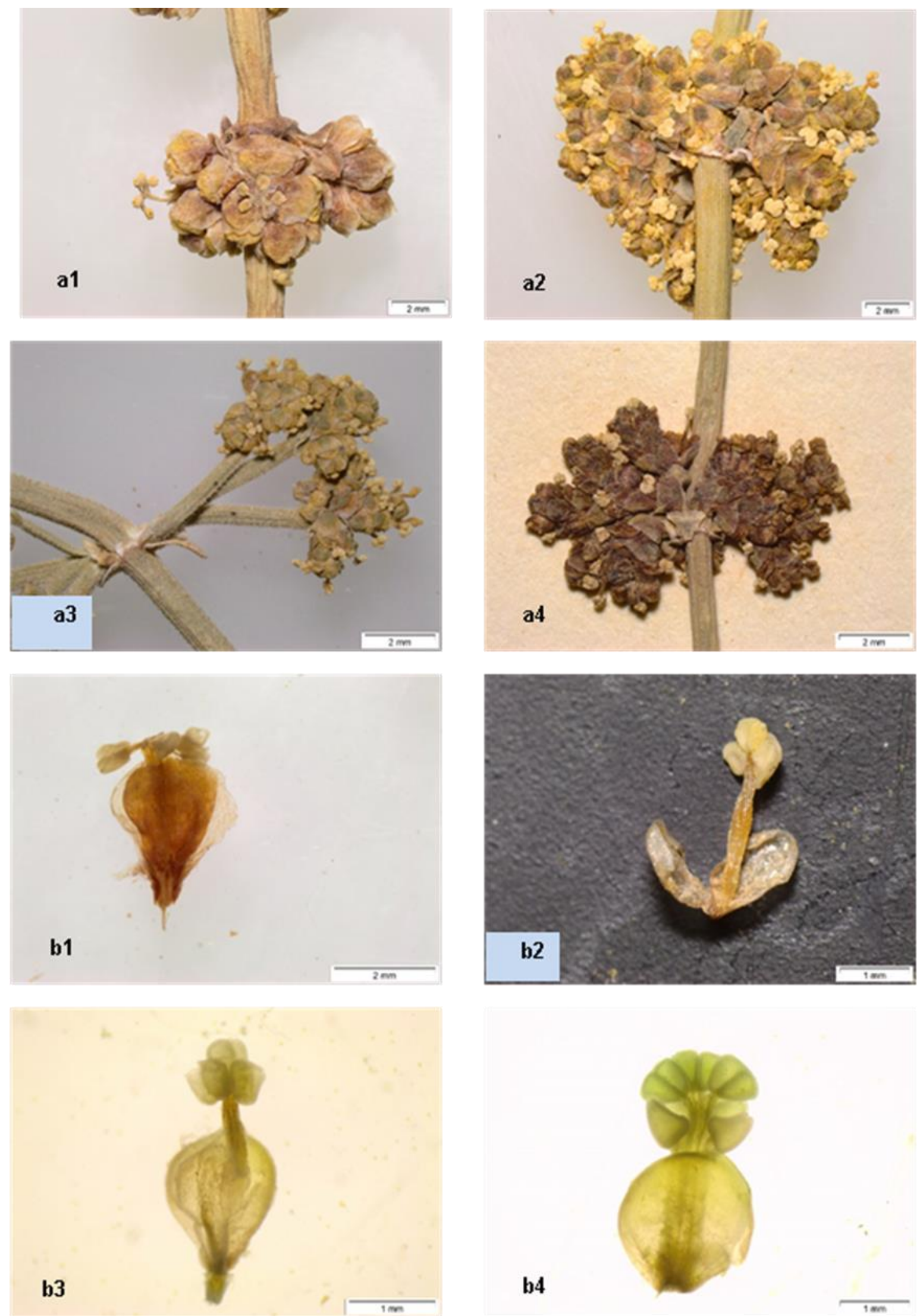

b4

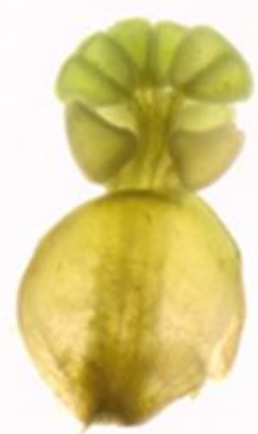

Figure (4): a, male cone; b, an enlarged male strobilus: 1, E. alata; 2, E. aphylla; 3, E. foliata; 4, E. pachyclada subsp. Sinaica 

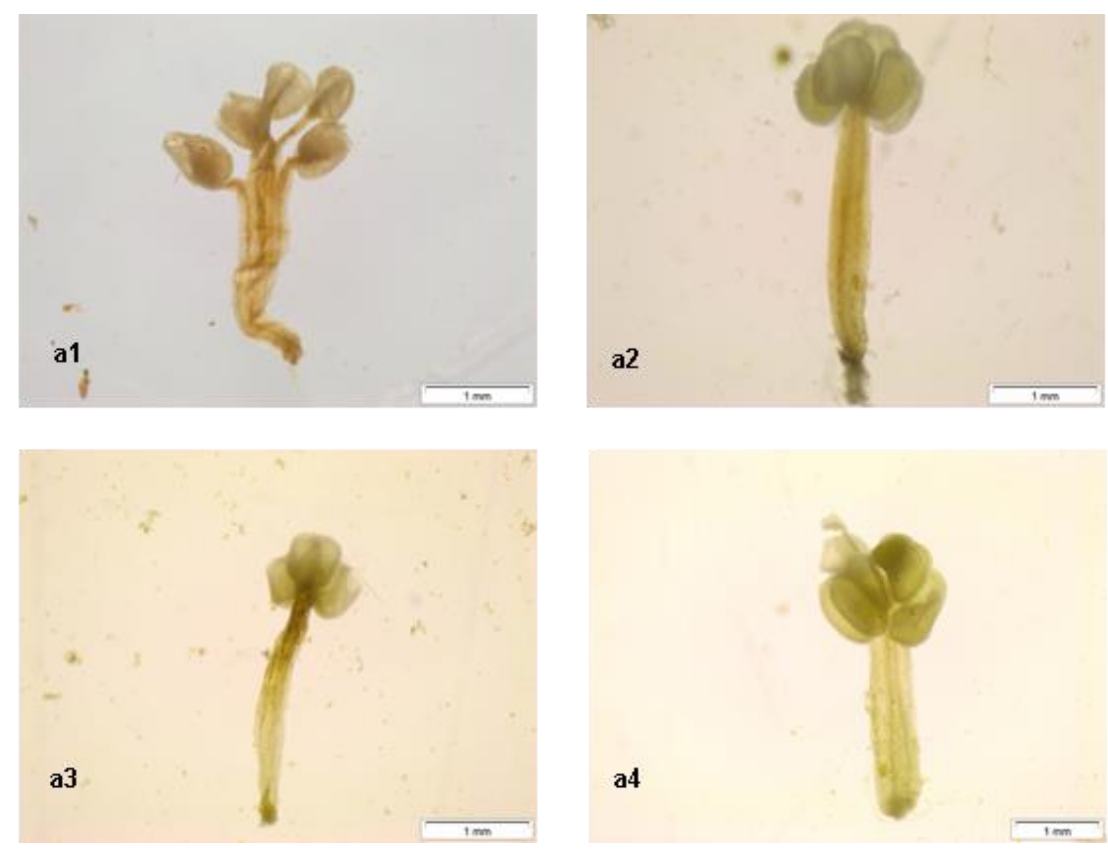

Figure (5): a, microsporangia and sporangiophore: 1, E. alata; 2, E. aphylla; 3, E. foliata; 4, E. pachyclada subsp. sinaica

Table (3): Main differential characters of the Ephedra species

\begin{tabular}{lcccc}
\hline \hline Character & E. alata & E. aphylla & E. foliata & E. pachyclada subsp. sinaica \\
\hline Leaf length (mm) & $2-2.5$ & $2-3$ & $10-17$ & $2-3$ \\
Margins of leaves and bracts & Ciliate & Ciliate & Ciliate & Glabrous \\
Stem surface & Smooth & Papillose & Ciliate & Papillose \\
Bracts of female cone & Free & Fused & Fused & Fused \\
Number of female cone bracts (pairs) & 5 & 3 & 2 & 4 \\
Length of innermost female flower & $4-5$ & $4-5$ & $6-8$ & $3-5$ \\
bracts (mm) & 2 & 1 & $1-2$ & 1 \\
Number of ovules per cone & $6-7$ & $6-7$ & $6-7$ & $4-5$ \\
Length of seed (mm) & Distinctly stipitate & Sessile & Sessile & Sessile \\
Anthers & $4-6$ & $3-4$ & $3-4$ & $5-8$ \\
Number of anthers per one flower & $2.5-2.8$ & $2.5-2.8$ & $2.4-2.6$ & $3-3.6$ \\
Length of stamens (mm) & & & & \\
\hline \hline
\end{tabular}

Table (4): PCR success and DNA sequence length of trn$\mathrm{H} / \mathrm{psb}-\mathrm{A}$ and ITS markers used in DNA barcoding and phylogenetic analysis of Egyptian Ephedra species.

\begin{tabular}{lcccc}
\hline \hline \multicolumn{1}{c}{ Taxa } & trn-H/psb-A & $\begin{array}{c}\text { Length } \\
(\mathbf{b p})\end{array}$ & ITS & Length (bp) \\
\hline Ephedra alata & + & 519 & - & $\mathbf{x}$ \\
E. aphylla & - & $\mathbf{x}$ & + & 356 \\
E. foeminea & - & $\mathbf{x}$ & - & $\mathbf{\times}$ \\
E. foliata & + & 541 & - & $\times$ \\
E. pachyclada & + & 536 & + & 357 \\
\hline \hline
\end{tabular}

(+) PCR successful, (-) PCR failed, numbers = length of sequence in base pair (bp), ( $\mathbf{x})$ sequence failed.

\section{Phylogeny}

The $t r n-\mathrm{H} / p s b-\mathrm{A}$ region had an aligned length of 541 bp while The ITS region had an aligned length of 357 bp. The combined alignment had an aligned length of 1094 bp (Table 4). By contrast, the trn-H/psb-A based Bayesian phylogenetic tree contained three internal nodes with a posterior probability (PP) of 1.0 (Fig. 6). The Bayesian 50\% majority rule consensus tree for ITS contained one internal node with (PP) of 1.0 (Fig. 7). The combined ITS and $t r n-\mathrm{H} / p s b$-A tree contained two internal nodes with a (PP) of 1.0 (Fig. 8).

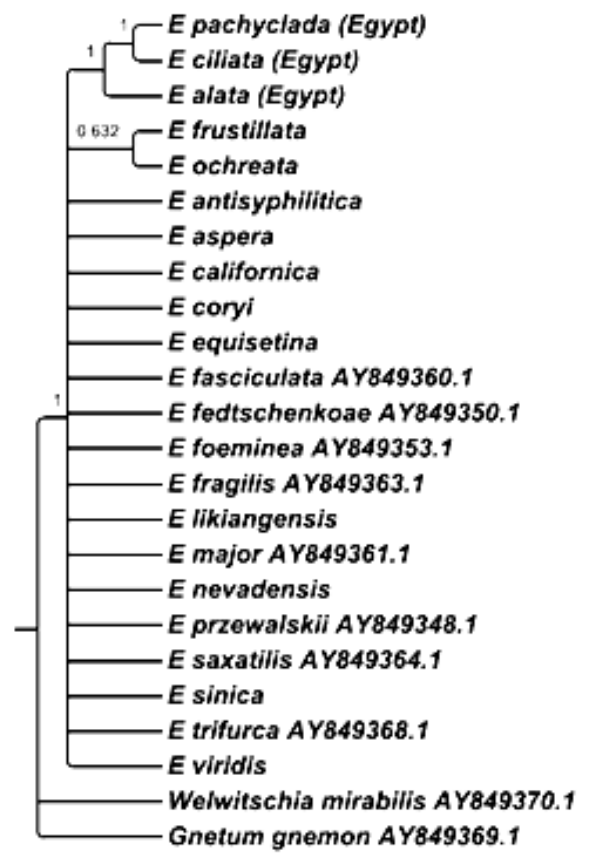

Figure (6): Cladogram of Bayesian 50\% majority rule consensus of $t r n-\mathrm{H} / p s b-\mathrm{A}$. of Egyptian Ephedra species. 
The phylogenetic analysis of the sequence dataset of the $t r n-\mathrm{H} / p s b$-A includes 24 Ephedra species as well as Welwitschia mirabilis and Gentum gnemon as outgroup. While the analysis of the ITS region includes 18 Ephedra species and one outgroup species. In the analysis of trn-H/psb-A; the Egyptian Ephedra species were represented by three species; Ephedra pachyclada, Ephedra ciliata and Ephedra alata. While in the analysis of the ITS region they were represented by two species Ephedra pachyclada and Ephedra aphylla.

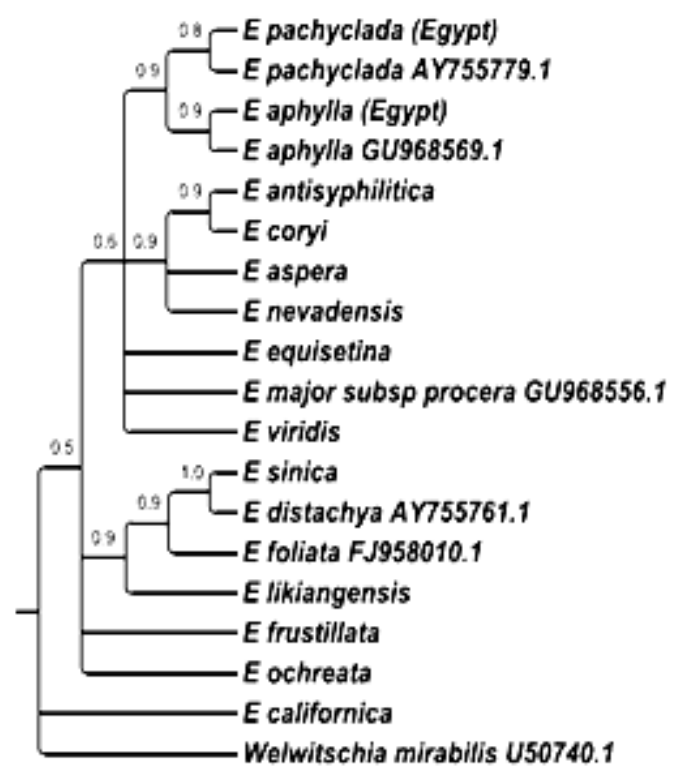

Figure (7): Cladogram of Bayesian 50\% majority-rule consensus of ITS of Egyptian Ephedra species

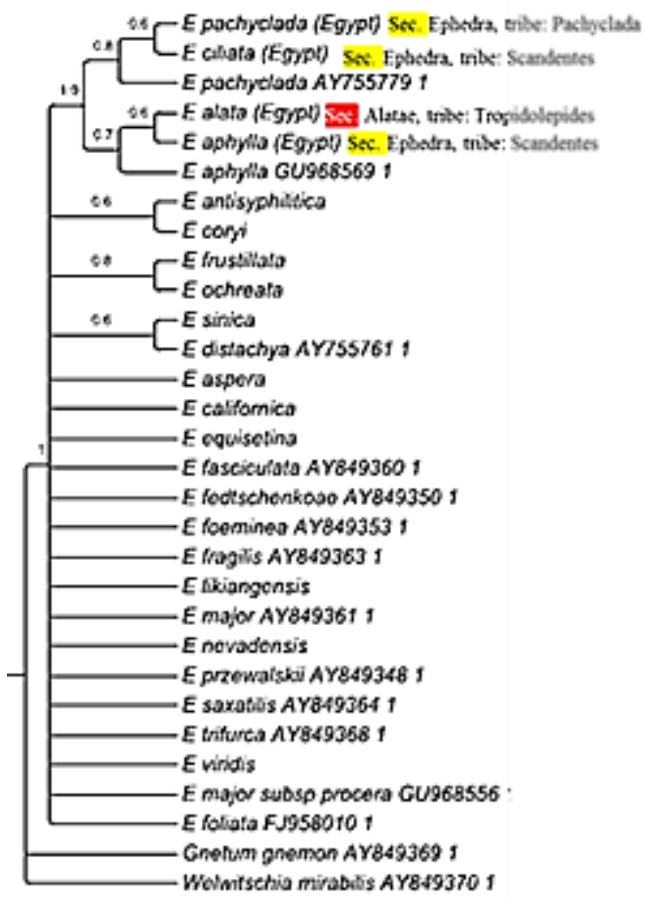

Figure (8): Cladogram of Bayesian all compatible tree inferred from combined datasets of $t r n-\mathrm{H} / p s b$-A and ITS markers of Ephedra species. Number above branches represents posterior probability of the branch.
The nucleotide substation model used was GTR+I+G for the both region. The analysis was run for one million generation and produced a total of 202 trees in two files; each file contained 101 trees of which 76 were sampled. The in group was composed of the 22 Ephedra species as well as two out group species in the trn-H/psb-A analysis and 18 Ephedra species and one out group in the ITS-based analysis. Bayesian Inference (BI) of all $50 \%$ majority rule consensus phylogenetic trees with accom-panying Posterior Probability (PP) for $t r n-\mathrm{H} / p s b$ $A$ and ITS region are presented in (Figures 6 and 7 respectively).

\section{DISCUSSION}

Due to the extremely reduced morphological characters of Ephedra and the trivial number of character states, the taxonomy of the genus Ephedra L. has always been doubtful and have a partial taxonomical studies (Ickert-Bond et al., 2003). The infrageneric relationships between Ephedra have been still uncertain and that because the most classification of the genus was based on limited vegetative characters such as leaf length, female cone bracts, number of seeds per female cone and plant habit (Huang et al., 2005). Meyer (1846) carried out the first and the earliest classification treatment of the genus. He divided the genus into two sections (Plagiostoma and Discostoma) based the morphology and the number of ovulate strobili at a node. The pioneer world-wide monograph of Ephedra is that of Stapf (1889) who divided the genus into three sections based on bract's nature in the ovulate cones namely Alatae, Ephedra and Asarca. Section Alatae Stapf is represented in Egypt by only $E$. alata under the tribe Tropidolepides. It characterized by dry, membranous, wavy winged, female cone bracts. Ephedra alata (Figures $2: \mathrm{b} 1 ; 3: \mathrm{b} 1 ; 4: \mathrm{a} 1)$ can easily distinguished from other Ephedra species by smooth stem surface, free; dry; marginal winged; 5 pairs of female cone bracts, 2 seeds and its anthers are distinctly stipitate (Boulos, 1999; El Hadidi, 2000; Ickert-Bond and Wojciechowski, 2004; Rydin et al., 2010; Zohary and Feinbrun-Dothan, 1966).

Section Ephedra Stapf (= section Pseudobacatae Stapf) is characterized by fleshy and un-winged female cone bracts. Two tribes (Scandentes and Pachyclada) were recognized in this section within Egyptian Ephedra. Tribe Scandentes represented in Egypt by Ephedra aphylla, Ephedra foliata and Ephedra foeminea, while Ephedra pachyclada subsp. sinaica was included in tribe Pachyclada. According to (El Hadidi, 2000; Freitag and Maier-Stolte, 1989; Freitag and Maier-Stolte, 1992; Hufford, 1996; Ickert-Bond and Wojciechowski, 2004; Price, 1996; Rydin et al., 2010; Zohary and Feinbrun-Dothan, 1966), margins of leaves and bracts was glabrous in Ephedra pachyclada, while being ciliate in both Ephedra aphylla and Ephedra ciliata (Figures 2-5, Table 3). Price (1996) reported that the systematical history and nomenclature of the Mediterranean species of Ephedra has been particularly complicated, and most of names such as E. alte, E. campylopoda 
and $E$. ciliata placed as a synonym. Our results revealed that Ephedra ciliata Fischer and C. A. Mey. is a synonym to Ephedra foliata Boiss. Recently, Ephedra foliata was used and accepted by many authors: (Dobignard and Chatelain, 2011; Freitag and Maier-Stolte, 2003; Govaerts, 2001; Hedberg et al., 2009; Miller and Morris, 2004).

Kress et al. (2005) recommended that the $t r n-\mathrm{H} / p s b$ A intergenic spacer is the best plastid choice for a DNA barcoding for land plants because it has excellent priming sites, length, and interspecific variation. Moreover, this intergenic spacer does present in non-flowering land plants. In an inquiry of Gene-Bank, we found that the $t r n-\mathrm{H} / p s b-\mathrm{A}$ has been efficiently amplified in angiosperms, gymnosperms, mosses, and liverworts. Our findings on the properties of $t r n-\mathrm{H} / p s b$-A agree with (Shaw et al., 2007) in their wide survey of non-coding plastid DNA for phylogenetic purposes. By applying standardized barcode criteria (i.e., length considerations and universality) to the framework of their study, we conclude that $t r n-\mathrm{H} / p s b-\mathrm{A}$ intergenic spacer has greater potential for species-level discrimination than the Internal Transcribed Spacer (ITS) for the Egyptian Ephedra species. For the first time in Egypt, we have shown that there are gene sequences suitable for DNA barcoding of non-flowering plants.

In non-flowering plants, to attain the species-level discrimination, it may be necessary to employ analysis of more than one locus. Our combined Bayesian analysis of $t r n-\mathrm{H} / p s b-\mathrm{A}$ and ITS confirmed that the Egyptian Ephedra species are polyphyletic. Nevertheless, the monophyly of Ephedra is generally unquestionable, and is maintained by other molecular phylogenetic research (Ickert-Bond, 2003), as well as a set of ecological features like xeromorphic characteristic and other morphological characters, including female cone bracts, stem texture and leave margin. Overall, our data do not provide sufficient phylogenetic resolution to draw conclusions concerning the monophyly or non-monophyly of Egyptian Ephedra. Despite the recovery of several wellsupported lineages in Egyptian Ephedra the basal branching relationships among these lineages is not well resolved by $t r n-\mathrm{H} / p s b-\mathrm{A}$, ITS, or the combined data (Figures 6, 7 and 8). However, it should be noted that trn-H/psb-A and ITS provide some evidence for the cohesiveness of Egyptian Ephedra species.

\section{Testing classification}

Our sampling of the Egyptian Ephedra species has given the prospect to test prevailing morphology-based hypotheses on infraspecific relationships. Our results reinforced the most recent infraspecific classification of the Egyptian Ephedra proposed by many authors. Although, the taxonomic investigations upheld the current sectional classification of the genus Ephedra in Egypt, the phylogenetic analysis uncovered irrational overlapping between two sections in Egypt. Ephedra alata which belongs to section Alatae was imbedded within species of the section Ephedra (Fig. 8). This overlapping could be explained that the genus Ephedra still in its route of speciation. This hypothesis is supported by obscured morphological features of the genus. The deli- mitation between the abovementioned two closely related sections is based on the morphological character of the female cone (dry or fleshy). Again, the female cone character is rather difficult to be traced in the available samples for the current work. The difficulty of the morphological identification and delimitation between Ephedra species in Egypt is still challenge. The current work recommends using the DNA barcode as a tool for species identification of Ephedra species as well as other gymnosperms in Egypt. This work will likely require wide sampling and sequencing of supplementary Loci from both the chloroplast and nuclear genome.

\section{ACKNOWLEDGMENTS}

Authors appreciate the help of the Biotechnology Institute for Graduate Studies and Research, Suez Canal University, Ismailia, Egypt. All institute's staff members were of much help to the authors to carry out the molecular part of the current study. Without their permission to authors to use their laboratory facilities such as thermal cycler as well as DNA sequencing machine, the current work wouldn't be completed.

\section{REFERENCES}

AKAIKE, H. 1974. A new look at the statistical model identification. IEEE transactions on automatic control 19: 716-723.

ANUEVA-ALMANZA, L., AND R. FONSECA, 2011. Taxonomic revision and geographic distribution of Ephedra (Ephedraceae) in Mexico. Acta Botanica Mexicana, 79-116.

BOULOS, L. 1999. "Flora of Egypt (AzollaceaeOxalidaceae)," Al-Hadara Publishing, Egypt.

BOULOS, L. 2009. "Flora of Egypt. Checklist," Al Hadara Publishing, Egypt.

CHRISTENHUSZ, M. J. M., AND J. W., BYNG. 2016. The number of known plants species in the world and its annual increase. Phytotaxa 261: 201-217.

CUTLER, H. C. 1939. Monograph of the North American species of the genus Ephedra. Annals of the Missouri Botanical Garden 26: 373-428.

DOBIGNARD, A., AND C. CHATELAIN. 2011. "Index synonymique de la flore d'Afrique du nord," Conserv. Jardin Bot. Genève, ECWP., Genève.

DOYLE, J. J., AND J. L. DOYLE. 1987. A rapid DNA isolation procedure for small quantities of fresh leaf tissue. Phytochem Bull 19: 11-15.

EISSA, T., O. PALOMINO, M. CARRETERO, AND M. GÓMEZ-SERRANILLOS. 2014. Ethnopharmacological study of medicinal plants used in the treatment of CNS disorders in Sinai Peninsula, Egypt. Journal of ethnopharmacology 151: 317-332.

EL-HADIDI, M. N., M. M. ABD-EL-GHANI, AND A. G. FAHMY. 1991. "The Plant Red Data Book of Egypt: Trees and Shrubs," Palm Press, Faculty of Science, Cairo University.

EL HADIDI, M.N. 2000. Flora Aegyptiaca. Vol. 1, part 2.Cairo: Palm Press iv, 170 p.illus. ISBN 1185154752.

FREITAG, H., AND M. MAIER-STOLTE. 1989. The Ephedra-species of P. Forsskål: identity and typifica 
tion. Taxon 38: 545-556.

FREITAG, H., AND M. MAIER-STOLTE. 1992. A new species and a new combination in the genus Ephedra from Arabia. Edinburgh Journal of Botany 49: 89-93.

FREITAG, H., AND M. MAIER-STOLTE. 1996. Ephedraceae. In "Flora of the Arabian Peninsula and Socotra" (A. G. Miller and T. A. Cope, eds.), Vol. 1, pp. 75-80. Edinburgh University Press, Edinburgh.

FREITAG, H., AND M. MAIER-STOLTE. 2003. The genus Ephedra in NE tropical Africa. Kew Bulletin 58: 415-426.

GOVAERTS, R. 2001. How many species of seed plants are there? Taxon 50: 1085-1090.

HEDBERG, I., I. FRIIS, AND E. PERSSON. 2009. "Flora of Ethiopia and Eritrea," National Herbarium, Addis Abeba University.

HUANG, J., D. E. GIANNASI, AND R. A. PRICE. 2005. Phylogenetic relationships in Ephedra (Ephedraceae) inferred from chloroplast and nuclear DNA sequences. Molecular Phylogenetics and Evolution 35: 48-59.

HUFFORD, L. 1996. The morphology and evolution of male reproductive structures of Gnetales. International Journal of Plant Sciences 157: S95S112.

ICKERT-BOND, S. M. 2003. "Systematics of New World Ephedra L. (Ephedraceae): integrating morphological and molecular data," Arizona state university, Arizona

ICKERT-BOND, S. M., AND C. RYDIN. 2011. Micromorphology of the seed envelope of Ephedra L.( Gnetales) and its relevance for the timing of evolutionary events. International journal of plant sciences 172: 36-48.

ICKERT-BOND, S. M., C. RYDIN, AND S. S. RENNER. 2009. A fossil-calibrated relaxed clock for Ephedra indicates an Oligocene age for the diver-gence of Asian and New World clades and Miocene dispersal into South America. Journal of Systematics and Evolution 47: 444-456.

ICKERT-BOND, S. M., J. J. SKVARLA, AND W. F. CHISSOE. 2003. Pollen dimorphism in Ephedra L. (Ephedraceae). Review of Palaeobotany and Palynology 124: 325-334.

ICKERT-BOND, S. M., AND M. F. WOJCIECHOWSKI. 2004. Phylogenetic relationships in Ephedra (Gnetales): evidence from nuclear and chloroplast DNA sequence data. Systematic Botany 29: 834849.

KRESS, W. J., K. J. WURDACK, E. A. ZIMMER, L. A.. WEIGT, AND D. H. JANZEN. 2005. Use of DNA barcodes to identify flowering plants. Proceedings of the National Academy of Sciences of the United States of America 102: 8369-8374.

LONG C. F., N. KAKIUCHI A. TAKAHASHI K. KOMATSU S. Q. CAI AND M., M. 2004. Phylogenetic analysis of the DNA sequence of the noncoding region of nuclear ribosomal DNA and chloroplast of Ephedra plants in China. Pl. Med. 70, 1080-1085.
MABBERLEY, D. J. 2008. "Mabberley's plant-book: a portable dictionary of plants, their classifications and uses," 3/Ed. Cambridge University Press, Cambridge

MEYER, C. 1846. Versuch einer Monographie der Gattung Ephedra, durch Abbildungen Erlaütet. Mém. Acad. Imp. St. Pétersb. Sér 6, Sci. Nat. 5: 225-298.

MILLER, A. G., AND M. MORRIS. 2004. "Ethnoflora of the Soqotra Archipelago," Royal Botanic Garden, Edinburgh.

MILLER, R. E., T. R. BUCKLEY, AND P. S. MANOS. 2002. Examination of the monophyly of morning glory taxa using Bayesian phylogenetic inference. . Systematic Biology 51: 740-753.

MUNDRY, M., AND T. STÜTZEL, 2004. Morphogenesis of the reproductive shoots of Welwitschia mirabilis and Ephedra distachya (Gnetales), and its evolutionary implications. Organisms Diversity and Evolution 4: 91-108.

NYLANDER, J. 2004. MrModeltest, version 2. Evolutionary Biology Centre, Uppsala University, Uppsala, Sweden.

PRICE, R. A. 1996. Systematics of the Gnetales: a review of morphological and molecular evidence. International Journal of Plant Sciences 157: S40-S49.

RAMBAUT, A., M. SUCHARD, AND A. DRUMMOND, 2013. Tracer, version 1.6 Computer program distributed by the authors. Department of Zoology, University of Oxford, Oxford, UK. Avilable at http://tree.bio.ed.ac.uk/.

RONQUIST, F., M. TESLENKO, P. VAN DER MARK, D. L. AYRES, A. DARLING, S. H“OHNA, B. LARGET, L. LIU, M. A. SUCHARD, AND J. P. HUELSENBECK. 2012. Efficient Bayesian phylogenetic inference and model selection across a large model space. Systematic Biology 61: 539-542.

RYDIN, C., M. KÄLLERSJÖ, AND E. M. FRIIS. 2002. Seed plant relationships and the systematic position of Gnetales based on nuclear and chloroplast DNA: conflicting data, rooting problems, and the monophyly of conifers. International Journal of Plant Sciences 163: 197-214.

RYDIN, C., A. KHODABANDEH, AND P. K. ENDRESS. 2010. The female reproductive unit of Ephedra (Gnetales): comparative morphology and evolutionary perspectives. Botanical Journal of the Linnean Society 163: 387-430.

RYDIN, C., K. R. PEDERSEN, P. R. CRANE, AND E. M. FRIIS, 2006. Former diversity of Ephedra (Gnetales): evidence from early Cretaceous seeds from Portugal and North America. Annals of Botany 98: $123-140$.

SHAW, J., E. D. LICKEY, E. E. SCHILLING, AND R. L. SMALL. 2007. Comparison Of Whole Chloroplast Genome Sequences To Choose Noncoding Regions For Phylogenetic Studies In Angiosperms: The Tortoise And The Hare III. American Journal of Botany 94: 275-288.

STAPF, O. 1889. "Die Arten der Gattung Ephedra," Kais. Akad.Wiss. Wien Math. Nat. Kl., Denkschr.

STÖVER, B. C., AND K. F. MÜLLER. 2010. TreeGr- 
aph 2: combining and visualizing evidence from different phylogenetic analyses. BMC bioinformatics 11: 7 .

SWOFFORD, D. L. 2003. PAUP*. Phylogenetic analysis using parsimony (*and other methods). Version 4.

TÄCKHOLM, V. 1974. "Students' Flora of Egypt," 2/Ed. Cairo University, Egypt.

TECHEN, N., I. PARVEEN, Z. PAN, AND I. A. KHAN. 2014. DNA barcoding of medicinal plant material for identification. Current Opinion in Biotechnology 25: 103-110

THIERS, B. 2017. Index herbariorum. A global direct- ory of public herbaria and associated staff. Vol. 2017. New York Botanical Garden's Virtual Herbarium, New York.

WCSP 2017. World Checklist of Selected Plant Families in the Catalogue of Life. The Catalogue of Life Partnership. Checklist Dataset.

ZHENG, Z. 1997. Yu J. Modern Study of Traditional Chinese Medicine, Beijing University of Traditional Chinese Medicine. Xue Yuan Press, Beijing, China.

ZOHARY, M., AND N. FEINBRUN-DOTHAN. 1966. "Flora Palaestina, Part 1, Equisetaceae to Moringaceae," The Israel Academy of Sciences and Humanities, Jerusalism.

\section{إعادة تقييم جنس الافيدرا (الفصيلة الافيدرية) في مصر باستخدام كل من الدلائل التصنيفية، الثفرة الوراثية وكذلك العلاقات التطورية}

$$
\begin{aligned}
& \text { احمد فريد'، احمد البنهاوي”، مسفر القحطانيّ }
\end{aligned}
$$

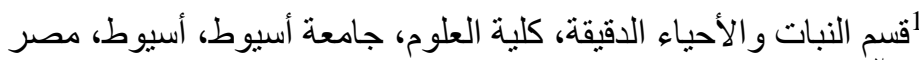

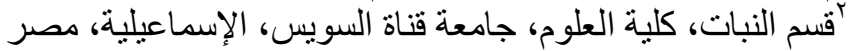

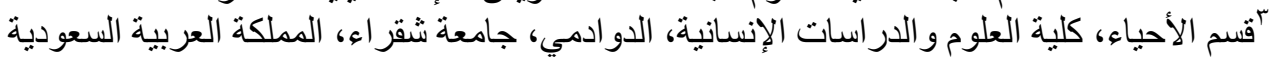

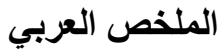

تم في هذه الدراسة اجر اء مر اجعة تصنيفية دقيقة لجنس الافيدرا في مصر بالاعتماد على الخصائص المورفولوجية للورقة، الساق وكذلك الزهرة. أيضا نم استخدام تقنية تتابع الثفرة الور اثية DNA sequencing لأول مرة على الفصيلة الافيدرية في مصر. تم استخدام ماركر من البلاستيدات الخضر اء (trn-H/psb-A) و اخر من النواة (ITS) لتأكيد تعريف الانو اع المصرية من Ephedra ciliata Fischer and C. A. جنس الافيدرا وكذلك لإعادة نوثيق العلاقات التطورية بينها. اسفرت النتائج ان اسم غير قانوني و اصبح مر ادف لـ .Ephedra foliata Boiss الذي ذكر هنا في هذه الدر اسة كاسم صحيح. اكدت النتائج انه يمكن استخدام تقنية الثفرة الور اثية DNA barcode كاداه لتعريف أنواع الافيدرا وكذلك الأنواع الأخرى من معرات البذور في 